\title{
Legacy in Cardiovascular Risk Factors Control: From Theory to Future Therapeutic Strategies?
}

\author{
Lucie Pothen (1) and Jean-Luc Balligand *(1) \\ Institute of Experimental and Clinical Research (IREC), Pharmacology and Therapeutics (FATH), \\ Cliniques Universitaires St-Luc and Université Catholique de Louvain (UCLouvain), 1200 Brussels, Belgium; \\ lucie.pothen@uclouvain.be \\ * Correspondence: jean-luc.balligand@uclouvain.be
}

check for updates

Citation: Pothen, L.; Balligand, J.-L. Legacy in Cardiovascular Risk Factors Control: From Theory to Future Therapeutic Strategies?. Antioxidants 2021, 10, 1849. https:// doi.org/10.3390/antiox10111849

Academic Editors: Guillermo Zalba and María U. Moreno Zulategui

Received: 1 October 2021

Accepted: 17 November 2021

Published: 22 November 2021

Publisher's Note: MDPI stays neutral with regard to jurisdictional claims in published maps and institutional affiliations.

Copyright: (c) 2021 by the authors. Licensee MDPI, Basel, Switzerland. This article is an open access article distributed under the terms and conditions of the Creative Commons Attribution (CC BY) license (https:/ / creativecommons.org/licenses/by/ $4.0 /)$.
Abstract: In medicine, a legacy effect is defined as the sustained beneficial effect of a given treatment on disease outcomes, even after cessation of the intervention. Initially described in optimized control of diabetes, it was also observed in clinical trials exploring intensification strategies for other cardiovascular risk factors, such as hypertension or hypercholesterolemia. Mechanisms of legacy were particularly deciphered in diabetes, leading to the concept of metabolic memory. In a more discreet manner, other memory phenomena were also described in preclinical studies that demonstrated long-lasting deleterious effects of lipids or angiotensin II on vascular wall components. Interestingly, epigenetic changes and reactive oxygen species (ROS) appear to be common features of "memory" of the vascular wall.

Keywords: metabolic memory; legacy effect; ROS; diabetes; hypertension; angiotensin II; oxLDL; hypercholesterolemia

\section{Introduction}

Cardiovascular diseases (CVDs) are the leading cause of death worldwide, with a major impact not only in developed nations but also in low- and middle-income countries, where they account for nearly 30 percent of all deaths [1]. Risk factors are well known: diabetes, hypercholesterolemia, smoking, hypertension, obesity, aging, familial history of early cardiovascular diseases, or sedentary lifestyle. Control of modifiable cardiovascular risk factors is essential to reduce the incidence of CVD, especially at early stages, before vascular damage develops [2,3]. Legacy in English refers to what one generation passes to the next or something that remains from an earlier time. In medicine, a legacy effect is defined as the sustained beneficial effect of a given treatment on disease outcomes or complications, even after cessation of the intervention. The term was initially used in the context of diabetes when long-term follow-up results of two diabetes management trials - the Diabetes Control and Complications Trial (DCCT) and the United Kingdom Prospective Diabetes Study (UKPDS)—were revealed [4,5]. A similar lasting effect was observed in lipid-lowering and blood pressure control trials [6].

In this paper, we reviewed clinical trials that revealed a legacy effect and established this concept in cardiovascular medicine. We searched in PubMed MEDLINE database for English written studies using specific terms: "legacy effect", "metabolic memory", "diabetes", "hypertension", and "hypercholesterolemia". A vast majority of included trials were randomized control trials, with an open label follow-up period (Table 1). In parallel, we summarized key data from basic research pointing to potential pathophysiological mechanism of legacy effects, based on previous studies on metabolic memory (Figure 1). 
Table 1. Studies evaluating legacy effect in cardiovascular risk factors control.

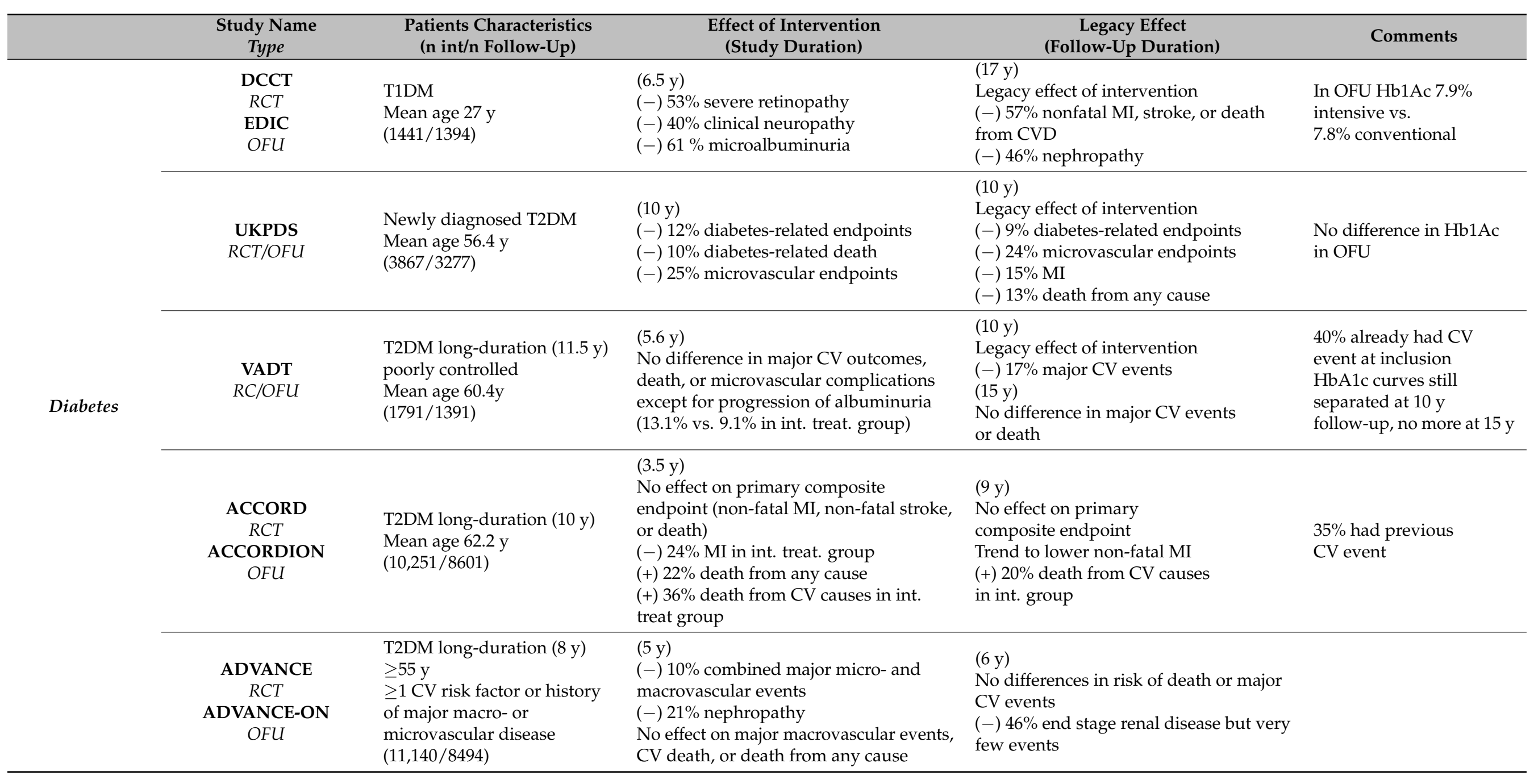


Table 1. Cont.

\begin{tabular}{|c|c|c|c|c|c|}
\hline & $\begin{array}{c}\text { Study Name } \\
\text { Type }\end{array}$ & $\begin{array}{l}\text { Patients Characteristics } \\
\text { (n int/n Follow-Up) }\end{array}$ & $\begin{array}{l}\text { Effect of Intervention } \\
\text { (Study Duration) }\end{array}$ & $\begin{array}{c}\text { Legacy Effect } \\
\text { (Follow-Up Duration) }\end{array}$ & Comments \\
\hline & $\begin{array}{c}\text { ADDITION } \\
\text { Registered based non-RCT }\end{array}$ & $\begin{array}{l}\text { Newly diagnosed T2DM after } \\
\text { screening compared to } \\
\text { unscreened population } \\
\text { Mean age } 59.9 \mathrm{y} \\
\text { (registered 153,107, } \\
\text { diagnosed 1533) }\end{array}$ & $\begin{array}{l}\text { (5 y screening period }) \\
\text { No comparison in intervention } \\
\text { Diabetes detected } 2.2 \text { y earlier in } \\
\text { screened group }\end{array}$ & $\begin{array}{l}(10 \text { y) } \\
\text { In screened group: } \\
\text { HR } 0.79 \text { lower mortality } \\
\text { HR } 0.80 \text { lower CV mortality } \\
\text { HR } 0.66 \text { lower diabetes-related mortality } \\
\text { HR } 0.84 \text { lower CVD event }\end{array}$ & $\begin{array}{l}\text { No effect at national } \\
\text { population level }\end{array}$ \\
\hline & $\begin{array}{c}\text { DAS } \\
\text { Cohort study }\end{array}$ & $\begin{array}{l}\text { Newly diagnosed T2DM } \\
\text { Mean age } 56.8 \text { y } \\
\text { Stratified by mean Hb1Ac } \\
\text { during first year, comparison } \\
\text { to } \mathrm{Hb} 1 \mathrm{Ac}<6.5 \% \\
(34,737)\end{array}$ & NA & $\begin{array}{l}(10 \mathrm{y}) \\
\text { - Hb1Ac } \geq 6.5 \% \text { within first year: } \\
\text { increased micro- and macro-CV events } \\
\text { (HR } 1.2) \\
\text { - Hb1Ac } \geq 7.0 \% \text { within first year, } \\
\text { increased mortality (HR } 1.29) \\
\text { - } \geq 8.0 \% \text { for more than } 2 \text { y increased } \\
\text { microvascular event and mortality risk }\end{array}$ & \\
\hline \multirow[t]{2}{*}{ Lipid profile } & $\begin{array}{l}\text { LIPID } \\
R C T \\
\text { LIPID FU } \\
\text { OFU }\end{array}$ & $\begin{array}{l}\text { Pravastatin vs. placebo in } \\
\text { recent MI or unstable angina } \\
\text { Median age } 62 \mathrm{y} \\
\text { Median cholesterol } \\
218 \mathrm{mg} / \mathrm{dl} \\
(9014 / 7680)\end{array}$ & $\begin{array}{l}\text { (6 y) } \\
\text { Vs. placebo: } \\
\text { (-) } 24 \% \text { RR death from CHD } \\
\text { (-) } 22 \% \text { RR overall mortality } \\
(-) 29 \% \text { RR MI } \\
(-) 19 \% \text { RR stroke }\end{array}$ & $\begin{array}{l}\text { (2 y) } \\
\text { Open-label period, crossover } \\
86 \% \text { gr. placebo on pravastatin } \\
88 \% \text { gr. prava still on pravastatin, with } \\
\text { similar cholesterol level } \\
\text { Legacy effect of intervention } \\
\text { (-) } 25 \% \text { RR death from CHD } \\
\text { (-) } 19 \% \text { RR overall mortality } \\
\text { (-) } 15 \% \text { RR MI } \\
(-) 24 \% \text { RR stroke }\end{array}$ & \\
\hline & $\begin{array}{l}\text { ASCOT-LLA } \\
R C T \\
\text { UK ASCOT-LLA } \\
\text { legacy } \\
\text { OFU }\end{array}$ & $\begin{array}{l}\text { Atorvastatin vs. placebo in } \\
\text { hypertensive patients with at } \\
\text { least } 3 \text { other CV risk factors } \\
\text { in primary prevention } \\
\text { Mean age } 61.4 \text { y } \\
(4605 / 4432)\end{array}$ & $\begin{array}{l}(3.3 \text { y) } \\
\text { Favor atorvastatin } \\
\text { HR } 0.64 \text { for non-fatal MI and fatal CHD } \\
\text { HR } 0.79 \text { for CV events } \\
\text { HR } 0.71 \text { for coronary events } \\
\text { Trend to less death (HR } 0.87, p=0.16)\end{array}$ & $\begin{array}{l}\text { (11 y) } \\
\text { Open-label crossover ( } 2 / 3 \text { placebo } \\
\text { on statin) } \\
\text { Legacy effect favored atorvastatin } \\
\text { HR } 0.86 \text { all-cause mortality } \\
\text { HR } 0.85 \text { non-CV death } \\
\text { HR } 0.89 \mathrm{CV} \text { death but not significant }\end{array}$ & \\
\hline
\end{tabular}


Table 1. Cont.

\begin{tabular}{|c|c|c|c|c|}
\hline $\begin{array}{c}\text { Study Name } \\
\text { Type }\end{array}$ & $\begin{array}{l}\text { Patients Characteristics } \\
\text { (n int/n Follow-Up) }\end{array}$ & $\begin{array}{l}\text { Effect of Intervention } \\
\text { (Study Duration) }\end{array}$ & $\begin{array}{c}\text { Legacy Effect } \\
\text { (Follow-Up Duration) }\end{array}$ & Comments \\
\hline $\begin{array}{l}\text { WOSCOPS } \\
R C T \\
\text { WOSCOPS FU } \\
\text { OFU }\end{array}$ & $\begin{array}{l}\text { Pravastatin vs. placebo in } \\
\text { primary prevention in men } \\
\text { Mean age } 55 \text { y } \\
\text { High LDL } \\
(6596 / 6408)\end{array}$ & $\begin{array}{l}(4.9 \text { y) } \\
\text { Favor pravastatin: } \\
\text { (-) } 31 \% \text { RR in non-fatal MI or death } \\
\text { from CHD } \\
(-) 32 \% \text { RR in death from CV causes }\end{array}$ & $\begin{array}{l}\text { (18 y) } \\
38.7 \% \text { (former prava) and } 35.2 \% \text { (former } \\
\text { placebo) at } 5 \text { y on statin, no further data } \\
\text { Legacy effect favored pravastatin: } \\
(-) 13 \% \text { mortality } \\
(-) 21 \% \text { RR in death from CV causes }\end{array}$ & \\
\hline $\begin{array}{l}\text { ACCORD-LLA } \\
\text { RCT } \\
\text { ACCORDION } \\
\text { OFU }\end{array}$ & $\begin{array}{l}\text { Combined therapy } \\
\text { (simvastatin + fibrate vs. } \\
\text { simva+ placebo) in T2D } \\
\text { long-duration with } \\
\text { dyslipidemia } \\
\text { Mean age } 61.8 \text { y } \\
(940 / 765)\end{array}$ & $\begin{array}{l}(5 \mathrm{y}) \\
\text { No effect of combined treatment on } \mathrm{CV} \\
\text { outcomes or mortality }\end{array}$ & $\begin{array}{l}(10 \mathrm{y}) \\
\text { Same level of lipid profile in both groups } \\
\text { but legacy effect of combined treatment } \\
\text { HR } 0.68 \text { in all-cause mortality } \\
\text { HR } 0.63 \text { in CVD mortality } \\
\text { HR } 0.66 \text { in major CHD }\end{array}$ & \\
\hline $\begin{array}{c}\text { HOPE-3 } \\
R C T \\
\text { HOPE-3 FU } \\
\text { OFU }\end{array}$ & $\begin{array}{l}\text { Rosuvastatin vs. placebo, at } \\
\text { least } 1 \mathrm{CV} \text { risk factor, no } \\
\text { CV disease } \\
\text { Mean age } 65.7 \mathrm{y} \\
(12,705 / 9326)\end{array}$ & $\begin{array}{l}\text { (5.6) } \\
\text { Favor rosuvastatin } \\
\text { HR } 0.76 \text { in MACE-1 (composite of death } \\
\text { from CV causes, non-fatal MI, } \\
\text { non-fatal stroke) } \\
\text { HR } 0.75 \text { in MACE2 (composite of } \\
\text { revascularization, HF, resuscitated CA) }\end{array}$ & $\begin{array}{l}\text { (3.1) } \\
\text { Legacy effect of rosuvastatin treatment } \\
\text { HR 0.80 MACE-1 } \\
\text { HR 0.83 MACE -2 } \\
\text { Total FU: } \\
\text { HR 0.79 MACE-1 } \\
\text { HR 0.79 MACE -2 }\end{array}$ & $\begin{array}{l}\text { In OFU: } 37 \% \text { on statin } \\
\text { ( } 36 \% \text { of former rosu, } 38 \% \\
\text { of former placebo group) }\end{array}$ \\
\hline $\begin{array}{l}\text { ALLHAT-LLT } \\
\text { RCT } \\
\text { ALLHAT-LLT } \\
\text { OFU }\end{array}$ & $\begin{array}{l}\text { Pravastatin vs. usual care in } \\
\text { hypertensive patient }+ \text { at } \\
\text { least } 1 \mathrm{CV} \text { risk factor } \\
\text { Mean age } 66 \text { y } \\
(10,355 / 1672)\end{array}$ & $\begin{array}{l}(4.8 \mathrm{y}) \\
\text { No effect on all-cause mortality or CHD }\end{array}$ & $\begin{array}{l}(8-13 \text { y) } \\
\text { No legacy effect }\end{array}$ & $\begin{array}{l}\text { Only } 16 \% \text { difference in } \\
\text { LDL between groups at } \\
\text { end of intervention } \\
\text { period }\end{array}$ \\
\hline
\end{tabular}


Table 1. Cont.

\begin{tabular}{|c|c|c|c|c|c|}
\hline & $\begin{array}{c}\text { Study Name } \\
\text { Type }\end{array}$ & $\begin{array}{l}\text { Patients Characteristics } \\
\text { (n int/n Follow-Up) }\end{array}$ & $\begin{array}{l}\text { Effect of Intervention } \\
\text { (Study Duration) }\end{array}$ & $\begin{array}{c}\text { Legacy Effect } \\
\text { (Follow-Up Duration) }\end{array}$ & Comments \\
\hline \multirow{4}{*}{ Blood pressure } & $\begin{array}{l}\text { SHEP } \\
\text { RCT } \\
\text { SHEP FU } \\
\text { OFU }\end{array}$ & $\begin{array}{l}\text { Chlortalidone }+/- \text { atenolol } \\
\text { vs. placebo in isolated } \\
\text { hypertensive patients } \\
\text { Mean age } 71.6 \mathrm{y} \\
(4736 / 1885)\end{array}$ & $\begin{array}{l}(4.5 \mathrm{y}) \\
\text { Favor intervention } \\
0.64 \mathrm{RR} \text { in stroke } \\
0.73 \mathrm{RR} \text { in non-fatal } \mathrm{MI}+0.46 \mathrm{RR} \\
\mathrm{LV} \text { failure }\end{array}$ & $\begin{array}{l}(22 \text { y) } \\
\text { Legacy effect of intervention } \\
\text { HR } 0.89 \mathrm{CV} \text { death } \\
\text { One day of life expectancy gained in } \\
\text { intervention group per month } \\
\text { of treatment }\end{array}$ & \\
\hline & $\begin{array}{c}\text { ROADMAP } \\
\text { RCT } \\
\text { ROADMAP OFU } \\
\text { OFU }\end{array}$ & $\begin{array}{l}\text { Olmesartan vs. placebo in } \\
\text { T2D patients } \geq 1 \mathrm{CV} \\
\text { risk factor } \\
\text { Mean age } 57.7 \mathrm{y} \\
(4447 / 1758)\end{array}$ & $\begin{array}{l}(3.2 \mathrm{y}) \\
\text { Increased time to onset of } \\
\text { microalbuminuria }(25 \%)\end{array}$ & $\begin{array}{l}(6 \text { y) } \\
\text { Despite crossover and increase in } \mathrm{BP}, \\
\text { legacy effect of olmesartan } \\
\text { OR } 0.34 \text { in diabetic retinopathy } \\
\text { OR } 0.23 \text { in CHF }\end{array}$ & $\begin{array}{l}\text { ! higher rate of fatal CV } \\
\text { events in int. group in } \\
\text { patients with } \\
\text { pre-existing CHD }\end{array}$ \\
\hline & $\begin{array}{c}\text { ASCOT } \\
R C T \\
\text { ASCOT legacy } \\
\text { OFU }\end{array}$ & $\begin{array}{l}\text { Amlodipine }(+/- \\
\text { perindopril) vs. atenolol } \\
(+/- \text { thiazide) } \\
\text { hypertensive patients } \geq 3 \\
\text { other CV risk factors } \\
\text { Mean age } 63 \text { y } \\
(19,257 / 8580)\end{array}$ & $\begin{array}{l}(5.5 \text { y) } \\
\text { Favor amlodipine-based regiment } \\
\text { HR } 0.77 \text { stroke (fatal and non-fatal) } \\
\text { HR } 0.84 \text { in CV events } \\
\text { HR } 0.76 \text { in CV mortality } \\
\text { HR } 0.70 \text { in new onset of diabetes }\end{array}$ & $\begin{array}{l}(16 \text { y) } \\
\text { Legacy effect of } \\
\text { amlodipine-based regiment } \\
\text { HR } 0.71 \text { death from stroke }\end{array}$ & \\
\hline & $\begin{array}{l}\text { UKPDS } 38 \\
\text { RCT } \\
\text { FU } \\
\text { OFU }\end{array}$ & $\begin{array}{l}\text { Tight vs. less-tight blood } \\
\text { pressure control T2DM } \\
\text { patients (captopril } \\
\text { and atenolol) } \\
\text { Mean age } 56.8 \text { y } \\
(1148 / 884)\end{array}$ & $\begin{array}{l}\text { (8.4 y) } \\
\text { Favor tight control } \\
\text { (-) } 24 \% \text { diabetes-related endpoints } \\
\text { (-) } 32 \% \text { diabetes-related deaths } \\
\text { (-) } 44 \% \text { strokes } \\
\text { (-) } 37 \% \text { microvascular endpoints }\end{array}$ & $\begin{array}{l}(10 \mathrm{y}) \\
\text { Legacy effect favored tight control } \\
0.50 \mathrm{RR} \text { in peripheral vascular disease }\end{array}$ & \\
\hline
\end{tabular}


Table 1. Cont.

\begin{tabular}{|c|c|c|c|c|}
\hline $\begin{array}{c}\text { Study Name } \\
\text { Type }\end{array}$ & $\begin{array}{l}\text { Patients Characteristics } \\
\text { (n int/n Follow-Up) }\end{array}$ & $\begin{array}{l}\text { Effect of Intervention } \\
\text { (Study Duration) }\end{array}$ & $\begin{array}{c}\text { Legacy Effect } \\
\text { (Follow-Up Duration) }\end{array}$ & Comments \\
\hline $\begin{array}{l}\text { HOPE-3 } \\
\text { RCT } \\
\text { HOPE-3 FU } \\
\text { OFU }\end{array}$ & $\begin{array}{l}\text { Candesartan }+\mathrm{HCTZ} \\
\text { vs. placebo } \\
\text { at least } 1 \mathrm{CV} \text { risk factor } \\
\text { No CV disease } \\
\text { Mean age } 65.7 \mathrm{y} \\
(12,705 / 9326)\end{array}$ & $\begin{array}{l}(5.6 \mathrm{y}) \\
\text { No significative difference, except in } \\
\text { subgroup }>143.5 \mathrm{mmHg} \\
\text { HR } 0.73 \text { MACE } 1 \\
\text { HR } 0.76 \text { MACE } 2\end{array}$ & $\begin{array}{l}(3.1 \mathrm{y}) \\
\text { Legacy effect in subgroup }>143.5 \mathrm{mmHg} \\
\text { HR 0.76 MACE } 1\end{array}$ & $\begin{array}{l}2 / 3 \text { in follow-up } 1 \geq \\
\text { BP-lowering drug and } \\
30 \% \text { on } 2 \geq B \text { B-lowering } \\
\text { drugs (similar in } \\
\text { both groups) }\end{array}$ \\
\hline $\begin{array}{l}\text { ALLHAT } \\
\text { RCT }\end{array}$ & $\begin{array}{l}\text { Hypertensive patients }+\geq 1 \\
\text { CHD risk factor, } \\
\text { chlortalidone vs. amlodipine } \\
\text { vs. lisinopril } \\
\text { Mean age } 67 \mathrm{y} \\
(32,804 / 27,755)\end{array}$ & $\begin{array}{l}(4.9 \mathrm{y}) \\
\text { No difference } \\
\text { Increase in HF for amlodipine } \\
\text { Increase in stroke mortality for lisinopril }\end{array}$ & $\begin{array}{l}(8-13 \text { y) } \\
\text { No legacy effect }\end{array}$ & \\
\hline $\begin{array}{c}\text { ANBP2 } \\
R C T \\
\text { ANBP2 FU } \\
\text { OFU }\end{array}$ & $\begin{array}{l}\text { Hypertensive patients } \\
\text { ACE inhibitor vs. diuretics } \\
\text { Mean age } 72 \text { y } \\
(6083 / 5378)\end{array}$ & $\begin{array}{l}(4.1 \text { y) } \\
\text { Favor ACE inhibition } \\
\text { HR } 0.89 \mathrm{CV} \text { event or death } \\
\text { HR } 0.68 \text { nonfatal MI } \\
\text { but } \\
\text { HR } 1.91 \text { for fatal stroke }\end{array}$ & $\begin{array}{l}(10 \text { y) } \\
\text { No legacy effect }\end{array}$ & $\begin{array}{l}\text { Different comparison in } \\
\text { OFU: treatment-naïve vs. } \\
\text { not naïve }\end{array}$ \\
\hline
\end{tabular}

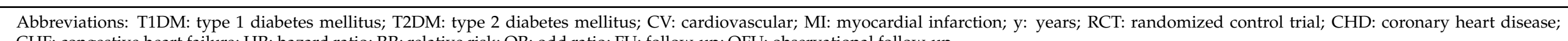
CHF: congestive heart failure; HR: hazard ratio; RR: relative risk; OR: odd ratio; FU: follow-up; OFU: observational follow-up. 
METABOLIC MEMORY

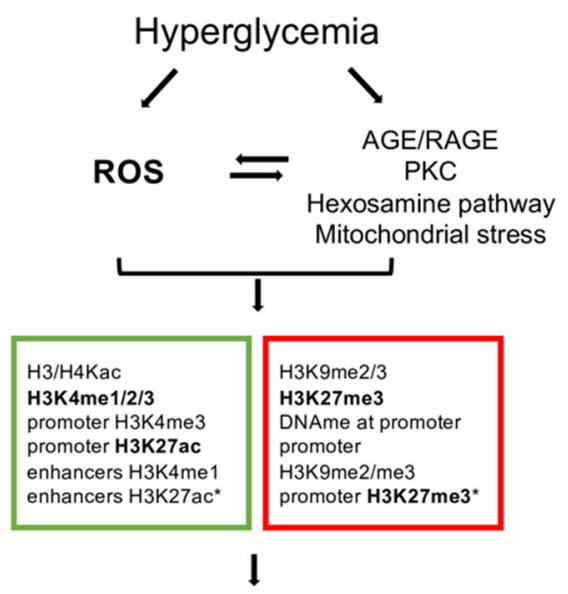

NFKBp65, ICAM, VCAM, p66SHC, eNOS ${ }^{*}, \ldots$

\section{I}

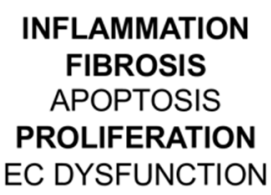

TRAINED IMMUNITY

OxLDL

I

HIF1

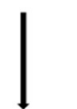

H3K4me3 个

H3K27ac $\uparrow$ S

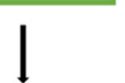

ICAM $\uparrow, \operatorname{VCAM} \uparrow$, MCP $\uparrow$, IL6 6 ,IL8 $\uparrow \$$

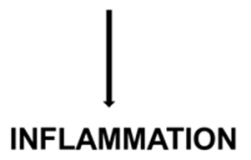

ANGII MEMORY

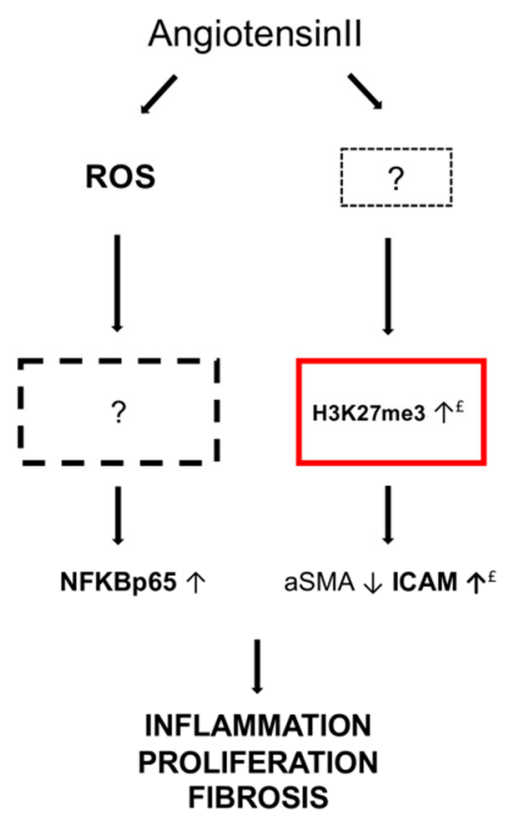

Figure 1. Mechanistic comparison of three memory theories in vascular research: metabolic memory, trained immunity, and Ang II memory. Common features are in bold type. Described epigenetic marks are listed in squares (red = repressive; green $=$ permissive). Based on: ${ }^{*}[7], \$[8]$ and ${ }^{£}$ [Pothen et al., unpublished data].

\section{Diabetes}

\subsection{Legacy Effect in Diabetic Patients}

Historically, the concept of the legacy effect emerged at the beginning of 21th century from two clinical studies conducted in diabetic patients (Table 1). The DCCT study was evaluating the effect of intensive control of glycemia compared to conventional therapy in a cohort of 1441 type 1 diabetic patients. After more than 6 years of intervention, the development of microvascular complications was significantly diminished in the intensive treatment group, i.e., severe retinopathy (by 53\%), clinical neuropathy (by $40 \%$ ), and microalbuminuria (by 61\%) [4]. After the trial, patients were followed for 17 years in the Epidemiology of Diabetes Interventions and Complications (EDIC) study. Despite interruption of the intensive control on glycemia $(7.9 \%$ of $\mathrm{Hb} 1 \mathrm{Ac}$ in previously intensive treatment group; $7.8 \%$ in conventional group), the authors observed a persistent reduction in the incidence of cardiovascular events (nonfatal MI, stroke, or death from CVD of 57\%) and nephropathy (of $46 \%$ ) in the former intensive treatment group [9].

Concordant results were observed later in UKPDS, a study conducted in 3867 newly diagnosed type 2 diabetic patients. In the intervention period, after a three-month diet, patients were randomized either to intensive glucose-lowering treatment (sulfonylurea, insulin, metformin) or to conventional dietary management and followed up for 10 years. Intensive glucose lowering was associated with a significant decrease in any diabetesrelated endpoint (of $12 \%$ ), any diabetes-related death (of 10\%), and microvascular endpoints (of $25 \%$ ). At this point, there was no significant reduction in macrovascular endpoints [5]. Another 10 years of follow-up of this cohort showed persistent benefit despite no difference in $\mathrm{HbA} 1 \mathrm{c}$ already after 1 year. In the former intensively treated group, the relative risk reductions persisted for any diabetes-related endpoint (by 9\%) and for microvascular 
disease (24\%) and were extended also for MI (by 15\%) and for death from any cause $(13 \%)[10]$.

Subsequently, several other studies failed to reproduce the same legacy effect: the Veterans Affairs Diabetes Trial (VADT) performed in long-standing type 2 diabetic patients [11-13], the Action to Control Cardiovascular Risk in Diabetes (ACCORD) trial with more than 10,000 long-lasting type 2 diabetic patients [14,15], or the Action in Diabetes and Vascular Disease Preterax and Diamicron (ADVANCE) study in 11,140 type 2 diabetic patients $[16,17]$. Long-term follow-up did not reveal any long-term benefit of the intervention period in all these cohorts. A common feature of these randomized trials was the inclusion of long-lasting diabetic patients (around 10 years of disease) and, in some studies, a high proportion of patients who already presented one cardiovascular event at randomization (e.g., VADT).

On the other hand, additional real-life studies reinforced the legacy effect theory in diabetes control, such as the Fremantle Diabetes Study [18], the Anglo-Danish-Dutch Study of Intensive Treatment in People with Screen-Detected Diabetes in Primary Care (ADDITION) [19,20], and the Diabetes and Aging Study (DAS) [21].

Taken together, the above-mentioned data suggest that to obtain a legacy effect, interventions on glycemic control need to be implemented early in the disease, certainly before any cardiovascular event, perhaps even within the first year. The accrued evidence then led to a new concept in diabetes clinical care: the sooner, the better.

Conversely, the failure to obtain a favorable effect from intensive treatment in longlasting, under-controlled diabetic patients could be ascribed to a "metabolic memory" underlying an adverse legacy effect, as explained below.

\section{2. "Metabolic Memory": What Is Hidden behind the Legacy Effect}

The phenomenon of "metabolic memory" had already been described in animal models before the concept of the legacy effect emerged from clinical studies. In 1987, in a dog model of diabetic retinopathy, Engerman et al. observed that animals with late onset optimization of glycemic control had a higher incidence of progression of this microvascular complication of diabetes [22]. A few years later, the word "memory" appeared in the scientific literature with the observation of lasting overexpression of fibronectin mRNA in several organs (e.g., kidney and heart) of streptozotocin-induced diabetic rats, despite restoration of euglycemia. The same authors observed overexpression of fibronectin and collagen IV in cultured endothelial cells exposed to hyperglycemia. This increased expression was sustained in time despite normalization of glucose concentration in culture media and subsequent cell passages [23]. The observation that early-but not late-islet transplantation, i.e., before retinal changes, prevented progression of retinopathy in sucrosefed diabetic Cohen rats further substantiated the memory theory [24]. Metabolic memory was further illustrated in several models in vitro and in vivo, including endothelial or vascular smooth muscle cells in culture, but also in animal models of atherosclerosis, diabetic nephropathy, and retinopathy $[25,26]$.

These models allowed the proposal of some putative mechanisms as follows: hyperglycemia induces an overproduction of mitochondrial superoxide. The ensuing oxidative stress leads to the activation of five major pathways: increased formation of AGEs (advanced glycation end products), expression of its receptor (RAGE), activation of protein kinase $\mathrm{C}$ isoforms, overactivity of the hexosamine pathway and polyol pathway that, in turn, activate inflammatory reactions. The same mediators also produce long-lasting epigenetic changes driving sustained expression of proinflammatory genes, despite restoration of glycemic control, leading to the observed hyperglycemic memory [27-30] (Figure 1). As an example, several histone lysine methylations were described following transient high glucose levels, associated with persistent transcriptional induction of the RELA gene, coding for the p65 subunit of NF-kB, despite subsequent incubation of cells with normal glucose concentrations; this led to transcriptional activation of target genes implicated in inflammation and endothelial dysfunction [31]. Indeed, hyperglycemia-dependent ROS production 
induced mono-methylation of histone 3 at lysine 4 amino-acid residue (H3K4me) by the methyltransferase Set7/9, a post-translational modification favoring gene transcription in mammals; the ensuing modification of histone binding the proximal promoter region of the RELA gene resulted in upregulation of the NF- $\mathrm{kB}$ subunit $\mathrm{p} 65$ and persistent vascular inflammation [29]. ROS production also induced CpG hypomethylation and increased $\mathrm{H} 3$ histone acetylation in the p66Shc promoter region; this mitochondrial adaptor, in turn, modulated the intracellular redox state, so ROS-induced epigenetic modifications were associated with higher levels of p66Shc and with significant activation of PKC, therefore sustaining oxidative stress, endothelial dysfunction, and vascular damages [32,33].

Moreover, upon epigenome profiling of white blood cells of patients from the DCCT trial, an enrichment of histone acetylation marks as promoters of inflammatory genes and other genes related to diabetic complications was observed in selected patients with progressive retinopathy and nephropathy compared to controls. This epigenetic mark also significantly correlated with the mean $\mathrm{HbA1C}$ during the trial [34].

\section{Hypercholesterolemia}

\subsection{Legacy Effect from Optimization of Lipid Profile}

As for diabetic patients and optimized glycemic control, lipid-lowering therapies also showed long-term benefit on cardiovascular outcomes (Table 1). In the Long-term Intervention with Pravastatin in Ischaemic Disease (LIPID) trial, pravastatin given in secondary prevention for 6 years reduced mortality and cardiovascular events in patients with previous acute coronary syndromes [35]. After a subsequent open-label period of 2 years, in which patients were offered pravastatin irrespective of their original assigned therapy, a sustained significant benefit of the initial intervention was observed on all-cause mortality, coronary heart disease mortality, myocardial infarction, and stroke [36].

In the Anglo-Scandinavian Cardiac Outcomes Trial-Lipid Lowering Arm (ASCOTLLA), 10,000 hypercholesterolemic and hypertensive patients with at least three other cardiovascular risk factors were randomized to receive either atorvastatin or placebo in primary prevention. The trial was stopped prematurely (median of 3.3 years of intervention) because of a $36 \%$ relative risk reduction in the primary outcome (consisting of non-fatal myocardial infarction and fatal coronary heart disease) in favor of atorvastatin and a non-significant reduction in CV deaths (of 16\%) and all-cause mortality (of 13\%) [37]. In the long-term follow-up (median of 11 years), all-cause mortality appeared significantly lower in patients originally assigned atorvastatin (decrease of $14 \%$ ). Fewer cardiovascular deaths were observed (11\% less; not significant), as well as non-cardiovascular deaths (15\%; reaching significance), in those formerly assigned atorvastatin, despite extensive crossover to statin treatment after the end of the initial trial. This reduction was intriguingly driven by a reduction in deaths due to infection and respiratory illness, raising still the unanswered question of the underlying mechanisms [38]. In the West of Scotland Coronary Prevention Study (WOSCOPS), men were proposed pravastatin as primary prevention or placebo for 5 years. Once again, on-trial statin treatment produced a beneficial effect vs. placebo on nonfatal myocardial infarctions (by 31\%), death from coronary heart disease (by $28 \%$ ), and death from all cardiovascular causes (by $32 \%$ ), despite low adherence at this point (only $38.7 \%$ of the intervention group were found to be on statins at 5 years) [39]. More than 20 years of follow-up revealed a sustained beneficial effect on all-cause mortality (by 13\%), attributable mainly to a $21 \%$ decrease in cardiovascular death [40], again despite crossover to statins in the original placebo group after the trial. The above-mentioned study ACCORD included a lipid arm (ACCORD-Lipid), in which type 2 diabetic patients were randomized to simvastatin plus fibrate or simvastatin plus placebo for 5 years. At the end of the intervention, there was no evidence of a beneficial effect of combined therapy compared to statins alone on cardiovascular outcomes and mortality [41]. However, the follow-up study (ACCORDION) showed that allocation to the combined fibrate-statin treatment arm during the trial period had a beneficial legacy effect on all-cause mortality $(35 \%)$, on top of decreased incidence rates of non-fatal myocardial infarction, congestive 
heart failure, major coronary heart disease, and CVD mortality [42]. The Heart Outcomes Prevention Evaluation (HOPE)-3 trial evaluated the benefit of lipid-lowering therapy (using rosuvastatin) and/or blood pressure optimization (using candesartan plus hydrochlorothiazide) in 12,000 intermediate-risk patients, e.g., patients with at least one cardiovascular risk factor, without any previous cardiovascular event. To note, inclusion in the trial did not mandate specific lipid or blood pressure levels before randomization. Each intervention was compared to placebo (the study included also combined treatment) for a duration of almost 6 years. Treatment with rosuvastatin was associated with a significant decrease (of $24 \%$ ) for the first coprimary outcome, namely MACE-1 (composite of death from CV causes, non-fatal myocardial infraction, non-fatal stroke), and consistently, with a significant decrease (of $25 \%$ ) for the second outcome, namely MACE-2 (composite of revascularization, heart failure, resuscitated cardiac arrest) [43]. In the recently published analysis of the long-term follow-up of 8.7 years, the benefit of rosuvastatin was maintained with a $21 \%$ reduction in risk of MACE-1 and a $21 \%$ reduction in risk of MACE- 2 for the total follow-up. To note, only $36 \%$ of patients initially randomized to rosuvastatin and $38 \%$ of those randomized to placebo were prescribed a statin after the active phase of the study [44]. A recent meta-analysis evaluated the legacy effect of lipid-lowering treatment by statins, analyzing eight randomized studies, either in primary or secondary prevention. Globally, direct in-trial effects were greater than post-trial effects (likely attributable to crossover effects), regarding cardiovascular and all-cause mortality. There was no evidence of significant legacy effect on CVD mortality, but some evidence of legacy effect on all-cause mortality; a subgroup analysis of the three trials performed as a primary prevention also demonstrated legacy effect on both CVD mortality (by 13\%) and all-cause mortality (by 10\%) [45].

The Antihypertensive and Lipid-Lowering Treatment to Prevent Heart Attack Trial (ALLHAT) included a subgroup in which hypertensive patients with a least another cardiovascular risk factor received pravastatin compared to usual care. No effect of the intervention was observed in all-cause mortality or coronary heart disease. This may be due to the modest differential in lipid profile between the intervention group and usual care group (16.7\% lower LDL-C compared to control). Moreover, the study was not blinded, at a period of publication of a series of guidelines stimulating optimization of the lipid profile and statin use contributed to treatment crossovers. Indeed, the trial follow-up showed a decrease in total cholesterol and LDL-C over time in both groups [46]. Consistently, long-term follow-up did not reveal any legacy effect of pravastatin in this trial [47]. The Second Australian National BP Study (ANBP2) was an open-label study including older hypertensive patients that was designed to compare two anti-hypertensive therapies. In a post hoc analysis of the ANBP2 cohort, patients were stratified according to lipid-lowering therapy at entry as the primary prevention versus usual care. Outcomes were compared regardless of their randomized treatment. Lipid-lowering treatment was significantly associated with a long-term (11 years) decrease in all-cause and non-CVD mortality (of $22 \%$ and $30 \%$, respectively); however, no statistically significant association with short-term mortality (4 years) was observed [48].

Beside the beneficial legacy effect of optimized control on lipid profile, long-term detrimental effects of a transient exposure to hypercholesterolemia have also been demonstrated. In a study in young adults born prematurely, endothelial function assessed by measurements of pulse wave velocity was compared between those who received intravenous lipids at early stage of life as part of parenteral nutrition and matched controls with equivalent perinatal characteristics who did not receive such supplements. Perinatal hyperlipemia secondary to intravenous lipids administration was associated with a significantly altered endothelial function compared to controls in adult life [49].

\subsection{Trained Immunity: oxLDL "Memory"}

As for metabolic memory, several in vitro studies evaluated the effects of transient exposure to lipoproteins on the vascular wall or its components, leading to the concept 
of trained immunity [50] resulting from the priming of different cell types with oxLDL (Figure 1).

Upon pre-incubation with oxLDL in vitro and further stimulation by a toll-like receptor (TLR) agonist, such as lipopolysaccharide (LPS) or lipopeptide PAM3cys4, endothelial cells expressed ICAM-1, VCAM-1, and E-selectin, which are adhesion molecules controlling rolling, adhesion, and transendothelial migration of leukocytes. In parallel, oxLDL priming also induced the enrichment of activating histone marks (H3K27ac and H3K4me3) on the ICAM-1 promoter [51]. In human coronary smooth muscle cells in vitro, oxLDL similarly induced a proinflammatory priming effect with a significant increase in IL6, IL8, and MCP1 production following restimulation with a TLR agonist. This increase was blocked by the inhibition of mTOR and TRL signaling pathways and by the histone methyltransferase inhibitor methylthioadenosine (MTA) [52]. Similar results were observed in isolated human monocytes pre-exposed to oxLDL in vitro: when primed by oxLDL (and not with non-oxidized LDL), subsequent stimulation with a TLR agonist, such as LPS, induced expression of several proatherogenic proteins (e.g., IL-6, TNF- $\alpha$, MCP-1, and MMP 2 and 9), enhanced foam cells formation, and increased H3K4me3 in promoter region of $T N F \alpha, I L-6, I L-18$, and $M C P-1$ genes. Pretreatment of monocytes with the histone methyltransferase inhibitor MTA completely prevented the oxLDL-induced proinflammatory phenotype [53]. Another pathway involved in oxLDL priming in monocytes in vitro is the production of ROS through mTOR activation of NADPH oxidase: cytosolic and mitochondrial ROS production was induced by oxLDL priming in monocytes in culture. This increase was blocked by pharmacological inhibition of mTOR, and the development of the trained immunity phenotype was blocked by antioxidant treatment [8]. Priming with oxLDL also has a major effect on metabolism in vascular wall cellular components with an increase in glycolysis and lactate production [50,54]. In preclinical studies in patients with established atherosclerosis, circulating monocytes also exhibited a higher production of pro-inflammatory cytokines upon LPS stimulation than healthy controls, associated with epigenetic remodeling (lower H3K27me3 on TNF $\alpha$ promoter) and increased expression of rate-limiting enzymes of the glycolysis pathway and the pentose phosphate pathway. Interestingly, this pro-inflammatory phenotype was present only in patients with severe symptomatic coronary atherosclerosis and not in patients with mild asymptomatic carotid atherosclerosis [55]. More recently, a concomitant upregulation of glycolytic activity and oxygen consumption was observed in oxLDL-primed human primary monocytes. In healthy volunteers, the impact of genetic variation (SNPs) in glycolytic genes on the training capacity of monocytes was evaluated: variants of genes encoding the inducible PFK-2/FBPase isozyme 6-phosphofructo-2-kinase/fructose-2,6-biphosphatase 3 (PFKFB3) and phosphofructokinase (PFKP) were associated with the potentiation of TNF- $\alpha$ and IL-6 production upon priming with oxLDL. Subsequent functional validation with inhibitors of glycolytic metabolism revealed dose-dependent inhibition of trained immunity in vitro. In vivo, the administration of metformin, a modulator of glucose metabolism, abrogated the ability of human monocytes to mount a trained response to oxLDL ex vivo [54].

\section{Hypertension}

\subsection{Legacy Effect of Optimized Blood Pressure Control}

Similar legacy findings were observed with blood pressure control (Table 1). A meta-analysis of 18 randomized clinical trials using blood pressure-lowering medications (including 132,854 patients in total) showed lower mortality (by 16\%) in the different intervention groups during the trial period. Mortality was also lower (by 15\%) during the open-label follow-up phases, when all of the patients were advised to take the same therapy, and rates of receiving active therapy were similar in the two groups [56]. In the Systolic Hypertension in the Elderly Program (SHEP) trial, chlortalidone-based therapy resulted in a lower rate of cardiovascular events (strokes, MI, and heart failure) at 4.5 years, but no significant effect on all-cause and cardiovascular mortality [57]. In the long-term follow-up of 22 years, a significant life expectancy gain, free from CVD-related death, was 
observed in the intervention group, corresponding to 1 day of life gained for each month of treatment [58]. In the Randomized Olmesartan and Diabetes Microalbuminuria Prevention (ROADMAP) trial, patients with type 2 diabetes with at least one other cardiovascular risk factor were assigned to receive either olmesartan or placebo for almost 3 years, with a principal favorable outcome of significantly delayed microalbuminuria onset in the intervention group [59]. In the observational follow-up of 3.3 years, despite an increase in mean systolic blood pressure in both groups, the incidences of diabetic retinopathy and congestive heart failure were significantly lower (OR 0.34 and 0.23 , respectively) in the original intervention group. Moreover, patients who developed microalbuminuria during the trial had a higher incidence of cardio- and cerebrovascular events (OR 1.77) [60].

The above-mentioned ASCOT study also included one arm of blood pressure control, in which patients were assigned either to an amlodipine-based regimen (with perindopril if required) or to atenolol (with bendroflumethiazide if required). Although mean blood pressure reduction was similar in both groups, cardiovascular events and all-cause mortality was significantly lower in the amlodipine (plus perindopril) group, suggesting that hypotensive medications are not equal in the prevention of CVD [61]. Long-term follow-up to 16 years showed no overall difference in all-cause mortality but significantly fewer deaths from stroke (by 29\%) in the amlodipine (plus perindopril) group [62]. The UKPDS trial also included a subgroup of newly diagnosed type 2 diabetic patients in which blood pressure control was optimized. Significant relative risk reductions were found during the trial for any diabetes-related end point, diabetes-related death, microvascular disease, and stroke in the group receiving tight compared to less-tight blood pressure control [63]. However, this effect was not sustained during the post-trial follow-up. Nevertheless, a risk reduction for peripheral vascular disease associated with tight blood pressure control remained significant after 10 years [64]. As previously mentioned, the HOPE-3 study included an arm to compare candesartan plus hydrochlorothiazide in intermediate-risk patients. No effect on both composite outcomes (MACE-1 and MACE-2) emerged after the intervention period, except in a subgroup of patients with high systolic blood pressure (>143.5 $\mathrm{mmHg}$ ), with a significant decrease of $27 \%$ and $24 \%$, respectively [65]. Long-term follow-up analysis revealed a legacy effect of combined therapy in the same subgroup of patients ( $>143.5 \mathrm{mmHg}$ ) with a significant decrease (of 24\%) in MACE-1 composite outcome [44].

Other randomized studies, however, failed to detect any legacy effect in blood pressure lowering. In the previously cited study ALLHAT, more than 30,000 patients were randomized to receive either chlorthalidone, amlodipine, or lisinopril for at least 4 years (active phase) with an observational period of 8 to 13 years afterward. No differential effect between these interventions was observed during the trial phase, explaining the absence of legacy effect [66]. As cited above, the Second Australian National BP Study (ANBP2) compared elderly patients in two different blood pressure-lowering regimens (perindopril vs. diuretics). A benefit of ACE inhibition on cardiovascular events and deaths was observed, particularly in men [67]. Long-term observational post hoc analysis failed to identified any legacy effect, when "treatment naïve" patients were compared to those treated at inclusion [68]. This result could be explained by one of the main limitations of this study, i.e., a non-randomized post hoc analysis performed in a cohort of older patients (mean age 71 years). In a meta-analysis of three randomized studies, including close to 5000 moderately hypertensive middle-aged patients, early initiation of antihypertensive treatment did not reduce cardiovascular morbidity or mortality compared to delayed initiation. No legacy effect was therefore observed in the long-term follow-up observational post hoc analysis [69].

Nevertheless, one class of blood pressure-lowering therapy emerged from clinical studies with a potential beneficial effect on cardiovascular outcomes beyond blood pressure lowering. In patients with heart failure resulting from myocardial infarction, a RAAS inhibitor led to prognosis improvement with only minimal (if any) effect on blood pressure [70]. Moreover, numerous studies in diabetic nephropathy demonstrated renal pro- 
tection by RAAS inhibition independent from its blood pressure-lowering effect. Further mechanistic studies led to the proposition that the reno-protection results from a decrease in angiotensin II-dependent glomerular efferent arteriolar tone, thereby reducing filtration pressure [70]. Finally, in the Losartan Intervention For Endpoint reduction in hypertension (LIFE) study, the AT1R blocking, RAAS inhibitor prevented more cardiovascular morbidity and deaths compared to atenolol, despite similar blood pressure reduction [71].

\subsection{Ang II "Memory"}

Angiotensin II, as the main product and effector of the RAAS stimulation, is a physiological regulator of blood pressure [72,73]. Infusions of Ang II are widely used experimentally to induce endothelial dysfunction or to mimic a hypertensive condition in vivo [74,75]. Contrary to the metabolic memory, published evidence on a putative memory effect of Ang II is scarce (Figure 1), aside from indirect causality inferred from the clinical trials with RAAS blockers, as reviewed above. A residual effect of temporary Ang II infusion on blood pressure and insulin sensitivity was observed in a study on young rats. A month after the end of infusion of a hypertensive dose of Ang II, blood pressure remained higher and insulin sensitivity was decreased in previously treated rats compared to saline-infused controls. These residual effects were attenuated by the co-administration of tempol, a free radical scavenger, or of candesartan together with Ang II during the infusion period, and the effects of candesartan were not mimicked by hydralazine at a dose producing a similar decrease in blood pressure; the data suggested a link with oxidative stress and an Ang II receptor specificity for this effect [76]. In another study on mice, a sustained vascular and heart injury was observed up to 1 week after withdrawal of an initial Ang II infusion with persistent activation of multiple signaling pathways (JNK1/2, STAT3, and NF- $\mathrm{KB}$ ) and an increase in ROS production; as the sustained effect was attenuated with apocynin, a NOX inhibitor, the data suggested a link with persistent NADPH oxidase activation. However, these studies did not investigate the upstream mechanism for the sustained oxidative stress, including through potential epigenetic regulation $[77,78]$. In the above-mentioned model, hypertension persisted during the week after Ang II withdrawal, introducing a confounding bias about its role in the persisting cardiac and vascular remodeling. More recently, we observed long-term (up to 3 weeks) detrimental effects of temporary Ang II infusion on heart and vascular integrity, linked to a sustained vascular smooth muscle cell phenotypic switch and down-regulation of $\alpha$-smooth muscle actin, associated with epigenetic marks (H3K27me3) and myocardin transcription factor repression [Pothen L et al.; unpublished data].

\section{Discussion}

This review of clinical trials testing optimized control of cardiovascular risk factors in at-risk patients provided convincing evidence in favor of a legacy effect, despite heterogeneity in study populations, duration of in-trial and follow-up periods, and clinical outcomes. A legacy effect was firmly established in diabetic patients, but also discernible in hypercholesterolemic and hypertensive patients. One common feature is that, to be effective and produce legacy, interventions on risk factors have to be implemented at early stages. The expression "the sooner the better" should therefore be extended from diabetes to the control of hypertension and hyperlipidemia.

The mechanisms underlying such legacy effects were thoroughly examined in diabetic conditions with preclinical models showing metabolic changes that led to sustained oxidative stress and epigenetic modifications; these, in turn, induced a feed-forward phenomenon (or "vicious circle") that perpetuated oxidative stress, inflammation, and damage to the vascular wall [7]. The mechanisms for trained immunity by exposure to oxLDL [50] or Ang II memory [76,77] [Pothen L et al., unpublished] are less well-characterized, but probably converge on, at least, some common effectors.

Even if pathophysiological mechanisms are not completely understood, the idea of an organ memory rather than memory specific to each risk factor is an attractive theory, 
which needs to be substantiated by further investigation, either through clinical trials or in vitro/in vivo studies. Arterial beds, for example, can be considered as a unique organ, consisting of highly sensitive and interacting cell types, directly in contact with blood flow where the inner endothelial cell lining could perpetuate oxidative stress induced by an initial aggressor; among these, oxLDL is known to produce endothelial dysfunction and to prime monocytes, thereby promoting pro-inflammatory susceptibility $[29,52]$; in response, the underlying vascular smooth muscle cells can (reversibly) alternate between a contractile or synthetic phenotype with more cytokines and extracellular matrix production resulting in sustained vascular remodeling. As all aggressors converge on the same resulting phenotype (e.g., atherosclerosis) and as they cumulate their effects together-indeed hypertension, lipid disorders, and diabetes often coexist within the same individual —one can imagine that despite differences in the initial steps of the disease, all cardiovascular risk factors lead to the same memory behavior of the vascular wall, just as rivers meet in the same sea.

Notably, epigenetic mechanisms appeared at the center of all the above-mentioned memory effects. In metabolic memory, several epigenetic changes (histone methylation, histone, and protein acetylation, $\mathrm{CpG}$ island methylation content, miRNA) were involved in the sustained oxidative stress in endothelial cells [7,30]. In trained immunity, H3K4me3 and H3K27ac were identified as marks of priming with oxLDL in monocytes [50] and endothelial cells [51], associated with the subsequent pro-inflammatory phenotype. In Ang II memory, we observed another repressive epigenetic mark in vascular smooth muscle cells (K3K27me3), associated with sustained phenotypic switch and vascular damage [Pothen L et al., unpublished]. Despite the lack of congruency in all these epigenetic changes, one can recognize that, albeit different, they share common features and lead to persistent activation of common effectors, consistent with the idea of an organized memory pattern of the arterial bed.

\section{Perspectives}

Some of the epigenetic changes at the basis of a legacy effect of precited cardiovascular risk factors were also implicated more broadly in the development of cardiometabolic diseases.

In another model of hypertension in vivo, spontaneously hypertensive rats (SHR) exhibited a significantly higher expression of angiotensin $1 \alpha$ receptor (AT1aR), encoded by Atgr1 $\alpha$, compared to Wistar-Kyoto control rats (WKY), which was associated with an hypomethylation of the Atgr1 $\alpha$ promoter [79]. In other studies, SHR rats also showed higher expression of Ace-1 mRNA and protein (compared to WKY controls) associated with $\mathrm{H} 3$ acetylation enrichment and H3K4me3 (activating marks) in Ace-1 promoter regions [79]. Insulin-resistant morbidly obese subjects have a different DNA methylation pattern in visceral adipose tissue, compared to insulin-sensitive ones, resulting in close to a $10 \%$ difference in diabetes-related expressed genes [80]. An epigenome-wide association study showed that elevated BMI was associated with changes in DNA methylation, mostly in genes involved in lipid and lipoprotein metabolism, substrate transport, and inflammatory pathways and that these alterations are related to adiposity [80]. Mice deficient in histone demethylase HDM2a, an enzyme responsible for H3K9 demethylation, developed an adult-onset obesity, hypertriglyceridemia, and hypercholesterolemia, as well as insulin resistance compared to wild type controls [81]. Sirtuins, a class of HDACs, were reported to act as metabolic regulators of glucose homeostasis, insulin resistance, and its associated inflammation. As an example, lack of SIRT1-, SIRT2-, and SIRT6-dependent deacetylation and activation of specific adipose gene programs was shown to contribute to the development of metabolic disorders, such as type 2 diabetes and obesity [81]. miRNA-mediated epigenetic changes also induce obesity-associated adipose tissue inflammation, a significant factor responsible for developing insulin resistance and type 2 diabetes. Accordingly, obese adipocyte-derived exosomes have an increased expression of miR-29a; when transferred into adipocytes, myocytes, and hepatocytes, these exosomes produced insulin resistance in both in vitro and in vivo models [81]. Of note, epigenetic changes are heritable and can be 
transmitted to the offspring. Transgenerational inheritance of specific epigenetic patterns was shown to affect expression of genes involved in vascular inflammation, oxidative stress, and atherosclerosis [80]

As epigenetic modifications are reversible, they could be interesting targets for innovative therapies. Histone deacetylase (HDAC) inhibitors were tested in experimental diabetes with some favorable effect: vorinostat, a nonspecific HDAC inhibitor, showed beneficial effects on diabetic nephropathy in mice [82]. An agonist of SIRT1, a class III HDAC that suppresses AGE-induced expression of profibrotic genes through an antioxidant effect, exerted a favorable effect on kidney injury in diabetic mice [83]. Inhibitors of histone methyltransferases were also studied [84]. Finally, siRNAs, antagomirs, or antisense oligonucleotides targeting epigenetic modifiers and lncRNAs/miRNAs demonstrated promising results [85]. Further studies will definitively be needed to design more specific inhibitors (HDAC-HMT) and to decrease off-target effects before evaluating their efficacy in the clinic.

\section{Conclusions}

In conclusion, clinical trials on the optimization of cardiovascular risk factors demonstrated the legacy effect of interventions on glycemic, lipid profile, or blood pressure control. While the mechanisms underlying this organ legacy are not yet fully understood, future investigations are expected to identify epigenetic signatures of "memory" that facilitate early detection of patients at risk and, possibly, lead to new therapeutic strategies by erasing them.

Author Contributions: Conceptualization, L.P. and J.-L.B.; methodology, L.P. and J.-L.B.; resources, L.P. and J.-L.B.; data curation, L.P. and J.-L.B.; writing-original draft preparation, L.P.; writingreview and editing, J.-L.B.; visualization, J.-L.B.; supervision, J.-L.B.; project administration, J.L.B.; funding acquisition, J.-L.B. All authors have read and agreed to the published version of the manuscript.

Funding: This research was funded by the Belgian Fond National de la Recherche Scientifique (FNRS, CDR J.309.21) and Fondation Saint Luc (Grant Pierre de Merre).

Conflicts of Interest: The authors declare no conflict of interest.

\section{References}

1. Fuster, V.; Kelly, B.B. (Eds.) Promoting Cardiovascular Health in the Developing World: A Critical Challenge to Achieve Global Health; The National Academies Collection: Reports Funded by National Institutes of Health; National Academies Press: Washington, DC, USA, 2010.

2. Parati, G.; Bilo, G.; Ochoa, J.E. Benefits of tight blood pressure control in diabetic patients with hypertension: Importance of early and sustained implementation of effective treatment strategies. Diabetes Care 2011, 34 (Suppl. 2), S297-S303. [CrossRef] [PubMed]

3. Zanchetti, A. Bottom blood pressure or bottom cardiovascular risk? How far can cardiovascular risk be reduced? J. Hypertens. 2009, 27, 1509-1520. [CrossRef] [PubMed]

4. Diabetes Control and Complications Trial Research Group. The effect of intensive treatment of diabetes on the development and progression of long-term complications in insulin-dependent diabetes mellitus. N. Engl. J. Med. 1993, 329, 977-986. [CrossRef] [PubMed]

5. UK Prospective Diabetes Study (UKPDS) Group. Intensive blood-glucose control with sulphonylureas or insulin compared with conventional treatment and risk of complications in patients with type 2 diabetes (UKPDS 33). Lancet 1998, 352, 837-853. [CrossRef]

6. Khunti, K.; Kosiborod, M.; Ray, K.K. Legacy benefits of blood glucose, blood pressure and lipid control in individuals with diabetes and cardiovascular disease: Time to overcome multifactorial therapeutic inertia? Diabetes Obes. Metab. 2018, 20,1337-1341. [CrossRef] [PubMed]

7. Natarajan, R. Epigenetic Mechanisms in Diabetic Vascular Complications and Metabolic Memory: The 2020 Edwin Bierman Award Lecture. Diabetes 2021, 70, 328-337. [CrossRef] [PubMed]

8. Sohrabi, Y.; Lagache, S.M.M.; Schnack, L.; Godfrey, R.; Kahles, F.; Bruemmer, D.; Waltenberger, J.; Findeisen, H.M. mTORDependent Oxidative Stress Regulates oxLDL-Induced Trained Innate Immunity in Human Monocytes. Front. Immunol. 2018, 9, 3155. [CrossRef] [PubMed]

9. Nathan, D.M.; Cleary, P.A.; Backlund, J.Y.; Genuth, S.M.; Lachin, J.M.; Orchard, T.J.; Raskin, P.; Zinman, B.; The Diabetes Control and Complications Trial/Epidemiology of Diabetes Interventions and Complications (DCCT/EDIC) Study Research Group. 
Intensive diabetes treatment and cardiovascular disease in patients with type 1 diabetes. N. Engl. J. Med. 2005, 353, $2643-2653$. [CrossRef] [PubMed]

10. Holman, R.R.; Paul, S.K.; Bethel, M.A.; Matthews, D.R.; Neil, H.A. 10-year follow-up of intensive glucose control in type 2 diabetes. N. Engl. J. Med. 2008, 359, 1577-1589. [CrossRef]

11. Duckworth, W.; Abraira, C.; Moritz, T.; Reda, D.; Emanuele, N.; Reaven, P.D.; Zieve, F.J.; Marks, J.; Davis, S.N.; Hayward, R.; et al. Glucose control and vascular complications in veterans with type 2 diabetes. N. Engl. J. Med. 2009, 360, 129-139. [CrossRef]

12. Hayward, R.A.; Reaven, P.D.; Wiitala, W.L.; Bahn, G.D.; Reda, D.J.; Ge, L.; McCarren, M.; Duckworth, W.C.; Emanuele, N.V.; Investigators, V. Follow-up of glycemic control and cardiovascular outcomes in type 2 diabetes. N. Engl. J. Med. 2015, 372, 2197-2206. [CrossRef] [PubMed]

13. Reaven, P.D.; Emanuele, N.V.; Wiitala, W.L.; Bahn, G.D.; Reda, D.J.; McCarren, M.; Duckworth, W.C.; Hayward, R.A.; Investigators, V. Intensive Glucose Control in Patients with Type 2 Diabetes-15-Year Follow-up. N. Engl. J. Med. 2019, 380, 2215-2224. [CrossRef] [PubMed]

14. Action to Control Cardiovascular Risk in Diabetes Study Group; Gerstein, H.C.; Miller, M.E.; Byington, R.P.; Goff, D.C., Jr.; Bigger, J.T.; Buse, J.B.; Cushman, W.C.; Genuth, S.; Ismail-Beigi, F.; et al. Effects of intensive glucose lowering in type 2 diabetes. N. Engl. J. Med. 2008, 358, 2545-2559. [CrossRef] [PubMed]

15. ACCORD Study Group. Nine-Year Effects of 3.7 Years of Intensive Glycemic Control on Cardiovascular Outcomes. Diabetes Care 2016, 39, 701-708. [CrossRef]

16. ADVANCE Colaborative Group; Patel, A.; MacMahon, S.; Chalmers, J.; Neal, B.; Billot, L.; Woodward, M.; Marre, M.; Cooper, M.; Glasziou, P.; et al. Intensive blood glucose control and vascular outcomes in patients with type 2 diabetes. N. Engl. J. Med. 2008, 358, 2560-2572. [CrossRef]

17. Zoungas, S.; Chalmers, J.; Neal, B.; Billot, L.; Li, Q.; Hirakawa, Y.; Arima, H.; Monaghan, H.; Joshi, R.; Colagiuri, S.; et al. Follow-up of blood-pressure lowering and glucose control in type 2 diabetes. N. Engl. J. Med. 2014, 371, 1392-1406. [CrossRef]

18. Davis, T.M.; Chubb, S.A.; Bruce, D.G.; Davis, W.A. Metabolic memory and all-cause death in community-based patients with type 2 diabetes: The Fremantle Diabetes Study. Diabetes Obes. Metab. 2016, 18, 598-606. [CrossRef]

19. Simmons, R.K.; Griffin, S.J.; Lauritzen, T.; Sandbaek, A. Effect of screening for type 2 diabetes on risk of cardiovascular disease and mortality: A controlled trial among 139,075 individuals diagnosed with diabetes in Denmark between 2001 and 2009. Diabetologia 2017, 60, 2192-2199. [CrossRef]

20. Simmons, R.K.; Griffin, S.J.; Witte, D.R.; Borch-Johnsen, K.; Lauritzen, T.; Sandbaek, A. Effect of population screening for type 2 diabetes and cardiovascular risk factors on mortality rate and cardiovascular events: A controlled trial among 1,912,392 Danish adults. Diabetologia 2017, 60, 2183-2191. [CrossRef]

21. Laiteerapong, N.; Ham, S.A.; Gao, Y.; Moffet, H.H.; Liu, J.Y.; Huang, E.S.; Karter, A.J. The Legacy Effect in Type 2 Diabetes: Impact of Early Glycemic Control on Future Complications (The Diabetes \& Aging Study). Diabetes Care 2019, 42, 416-426. [CrossRef]

22. Engerman, R.L.; Kern, T.S. Progression of incipient diabetic retinopathy during good glycemic control. Diabetes 1987, 36, 808-812. [CrossRef]

23. Roy, S.; Sala, R.; Cagliero, E.; Lorenzi, M. Overexpression of fibronectin induced by diabetes or high glucose: Phenomenon with a memory. Proc. Natl. Acad. Sci. USA 1990, 87, 404-408. [CrossRef] [PubMed]

24. Hammes, H.P.; Klinzing, I.; Wiegand, S.; Bretzel, R.G.; Cohen, A.M.; Federlin, K. Islet transplantation inhibits diabetic retinopathy in the sucrose-fed diabetic Cohen rat. Investig. Ophthalmol. Vis. Sci. 1993, 34, 2092-2096.

25. Reddy, M.A.; Zhang, E.; Natarajan, R. Epigenetic mechanisms in diabetic complications and metabolic memory. Diabetologia 2015, 58, 443-455. [CrossRef]

26. Villeneuve, L.M.; Reddy, M.A.; Natarajan, R. Epigenetics: Deciphering its role in diabetes and its chronic complications. Clin. Exp. Pharmacol. Physiol. 2011, 38, 451-459. [CrossRef]

27. Giacco, F.; Brownlee, M. Oxidative stress and diabetic complications. Circ. Res. 2010, 107, 1058-1070. [CrossRef] [PubMed]

28. Brownlee, M. The pathobiology of diabetic complications: A unifying mechanism. Diabetes 2005, 54, 1615-1625. [CrossRef]

29. Paneni, F.; Volpe, M.; Luscher, T.F.; Cosentino, F. SIRT1, p66(Shc), and Set7/9 in vascular hyperglycemic memory: Bringing all the strands together. Diabetes 2013, 62, 1800-1807. [CrossRef]

30. Jin, J.; Wang, X.; Zhi, X.; Meng, D. Epigenetic regulation in diabetic vascular complications. J. Mol. Endocrinol. 2019, 63, R103-R115. [CrossRef]

31. Brasacchio, D.; Okabe, J.; Tikellis, C.; Balcerczyk, A.; George, P.; Baker, E.K.; Calkin, A.C.; Brownlee, M.; Cooper, M.E.; El-Osta, A. Hyperglycemia induces a dynamic cooperativity of histone methylase and demethylase enzymes associated with gene-activating epigenetic marks that coexist on the lysine tail. Diabetes 2009, 58, 1229-1236. [CrossRef]

32. Paneni, F.; Mocharla, P.; Akhmedov, A.; Costantino, S.; Osto, E.; Volpe, M.; Luscher, T.F.; Cosentino, F. Gene silencing of the mitochondrial adaptor p66(Shc) suppresses vascular hyperglycemic memory in diabetes. Circ. Res. 2012, 111, 278-289. [CrossRef] [PubMed]

33. De Rosa, S.; Arcidiacono, B.; Chiefari, E.; Brunetti, A.; Indolfi, C.; Foti, D.P. Type 2 Diabetes Mellitus and Cardiovascular Disease: Genetic and Epigenetic Links. Front. Endocrinol. 2018, 9, 2. [CrossRef]

34. Miao, F.; Chen, Z.; Genuth, S.; Paterson, A.; Zhang, L.; Wu, X.; Li, S.M.; Cleary, P.; Riggs, A.; Harlan, D.M.; et al. Evaluating the role of epigenetic histone modifications in the metabolic memory of type 1 diabetes. Diabetes 2014, 63, 1748-1762. [CrossRef] 
35. Long-Term Intervention with Pravastatin in Ischaemic Disease (LIPID) Study Group. Prevention of cardiovascular events and death with pravastatin in patients with coronary heart disease and a broad range of initial cholesterol levels. N. Engl. J. Med. 1998, 339, 1349-1357. [CrossRef] [PubMed]

36. Group, L.S. Long-term effectiveness and safety of pravastatin in 9014 patients with coronary heart disease and average cholesterol concentrations: The LIPID trial follow-up. Lancet 2002, 359, 1379-1387. [CrossRef]

37. Sever, P.S.; Dahlof, B.; Poulter, N.R.; Wedel, H.; Beevers, G.; Caulfield, M.; Collins, R.; Kjeldsen, S.E.; Kristinsson, A.; McInnes, G.T.; et al. Prevention of coronary and stroke events with atorvastatin in hypertensive patients who have average or lower-than-average cholesterol concentrations, in the Anglo-Scandinavian Cardiac Outcomes Trial-Lipid Lowering Arm (ASCOT-LLA): A multicentre randomised controlled trial. Lancet 2003, 361, 1149-1158. [CrossRef] [PubMed]

38. Sever, P.S.; Chang, C.L.; Gupta, A.K.; Whitehouse, A.; Poulter, N.R.; Investigators, A. The Anglo-Scandinavian Cardiac Outcomes Trial: 11-year mortality follow-up of the lipid-lowering arm in the U.K. Eur. Heart J. 2011, 32, 2525-2532. [CrossRef]

39. Shepherd, J.; Cobbe, S.M.; Ford, I.; Isles, C.G.; Lorimer, A.R.; MacFarlane, P.W.; McKillop, J.H.; Packard, C.J. Prevention of coronary heart disease with pravastatin in men with hypercholesterolemia. West of Scotland Coronary Prevention Study Group. N. Engl. J. Med. 1995, 333, 1301-1307. [CrossRef]

40. Ford, I.; Murray, H.; McCowan, C.; Packard, C.J. Long-Term Safety and Efficacy of Lowering Low-Density Lipoprotein Cholesterol With Statin Therapy: 20-Year Follow-Up of West of Scotland Coronary Prevention Study. Circulation 2016, 133, 1073-1080. [CrossRef]

41. Group, A.S.; Ginsberg, H.N.; Elam, M.B.; Lovato, L.C.; Crouse, J.R., 3rd; Leiter, L.A.; Linz, P.; Friedewald, W.T.; Buse, J.B.; Gerstein, H.C.; et al. Effects of combination lipid therapy in type 2 diabetes mellitus. N. Engl. J. Med. 2010, 362, 1563-1574. [CrossRef]

42. Zhu, L.; Hayen, A.; Bell, K.J.L. Legacy effect of fibrate add-on therapy in diabetic patients with dyslipidemia: A secondary analysis of the ACCORDION study. Cardiovasc. Diabetol. 2020, 19, 28. [CrossRef] [PubMed]

43. Yusuf, S.; Bosch, J.; Dagenais, G.; Zhu, J.; Xavier, D.; Liu, L.; Pais, P.; Lopez-Jaramillo, P.; Leiter, L.A.; Dans, A.; et al. Cholesterol Lowering in Intermediate-Risk Persons without Cardiovascular Disease. N. Engl. J. Med. 2016, 374, 2021-2031. [CrossRef] [PubMed]

44. Bosch, J.; Lonn, E.M.; Jung, H.; Zhu, J.; Liu, L.; Lopez-Jaramillo, P.; Pais, P.; Xavier, D.; Diaz, R.; Dagenais, G.; et al. Lowering cholesterol, blood pressure, or both to prevent cardiovascular events: Results of 8.7 years of follow-up of Heart Outcomes Evaluation Prevention (HOPE)-3 study participants. Eur. Heart J. 2021, 42, 2995-3007. [CrossRef]

45. Nayak, A.; Hayen, A.; Zhu, L.; McGeechan, K.; Glasziou, P.; Irwig, L.; Doust, J.; Gregory, G.; Bell, K. Legacy effects of statins on cardiovascular and all-cause mortality: A meta-analysis. BMJ Open 2018, 8, e020584. [CrossRef]

46. ALLHAT Officers and Coordinators for the ALLHAT Collaborative Research Group. Major outcomes in moderately hypercholesterolemic, hypertensive patients randomized to pravastatin vs usual care: The Antihypertensive and Lipid-Lowering Treatment to Prevent Heart Attack Trial (ALLHAT-LLT). JAMA 2002, 288, 2998-3007. [CrossRef] [PubMed]

47. Margolis, K.L.; Davis, B.R.; Baimbridge, C.; Ciocon, J.O.; Cuyjet, A.B.; Dart, R.A.; Einhorn, P.T.; Ford, C.E.; Gordon, D.; Hartney, T.J.; et al. Long-term follow-up of moderately hypercholesterolemic hypertensive patients following randomization to pravastatin vs usual care: The Antihypertensive and Lipid-Lowering Treatment to Prevent Heart Attack Trial (ALLHAT-LLT). J. Clin. Hypertens. 2013, 15, 542-554. [CrossRef]

48. Ho, C.L.B.; Chowdhury, E.K.; Breslin, M.; Doust, J.; Reid, C.M.; Wing, L.M.H.; Nelson, M.R.; 2nd Australian National Blood Pressure Study Management Committee. Short- and long-term association of lipid-lowering drug treatment and cardiovascular disease by estimated absolute risk in the Second Australian National Blood Pressure study. J. Clin. Lipidol. 2019, 13, 148-155. [CrossRef]

49. Lewandowski, A.J.; Lazdam, M.; Davis, E.; Kylintireas, I.; Diesch, J.; Francis, J.; Neubauer, S.; Singhal, A.; Lucas, A.; Kelly, B.; et al. Short-term exposure to exogenous lipids in premature infants and long-term changes in aortic and cardiac function. Arterioscler. Thromb. Vasc. Biol. 2011, 31, 2125-2135. [CrossRef]

50. Sohrabi, Y.; Godfrey, R.; Findeisen, H.M. Altered Cellular Metabolism Drives Trained Immunity. Trends Endocrinol. Metab. 2018, 29, 602-605. [CrossRef]

51. Sohrabi, Y.; Lagache, S.M.M.; Voges, V.C.; Semo, D.; Sonntag, G.; Hanemann, I.; Kahles, F.; Waltenberger, J.; Findeisen, H.M. OxLDL-mediated immunologic memory in endothelial cells. J. Mol. Cell. Cardiol. 2020, 146, 121-132. [CrossRef]

52. Schnack, L.; Sohrabi, Y.; Lagache, S.M.M.; Kahles, F.; Bruemmer, D.; Waltenberger, J.; Findeisen, H.M. Mechanisms of Trained Innate Immunity in oxLDL Primed Human Coronary Smooth Muscle Cells. Front. Immunol. 2019, 10, 13. [CrossRef] [PubMed]

53. Bekkering, S.; Quintin, J.; Joosten, L.A.; van der Meer, J.W.; Netea, M.G.; Riksen, N.P. Oxidized low-density lipoprotein induces long-term proinflammatory cytokine production and foam cell formation via epigenetic reprogramming of monocytes. Arterioscler. Thromb. Vasc. Biol. 2014, 34, 1731-1738. [CrossRef]

54. Keating, S.T.; Groh, L.; Thiem, K.; Bekkering, S.; Li, Y.; Matzaraki, V.; van der Heijden, C.; van Puffelen, J.H.; Lachmandas, E.; Jansen, T.; et al. Rewiring of glucose metabolism defines trained immunity induced by oxidized low-density lipoprotein. J. Mol. Med. 2020, 98, 819-831. [CrossRef] [PubMed]

55. Bekkering, S.; van den Munckhof, I.; Nielen, T.; Lamfers, E.; Dinarello, C.; Rutten, J.; de Graaf, J.; Joosten, L.A.; Netea, M.G.; Gomes, M.E.; et al. Innate immune cell activation and epigenetic remodeling in symptomatic and asymptomatic atherosclerosis in humans in vivo. Atherosclerosis 2016, 254, 228-236. [CrossRef] [PubMed] 
56. Kostis, W.J.; Thijs, L.; Richart, T.; Kostis, J.B.; Staessen, J.A. Persistence of mortality reduction after the end of randomized therapy in clinical trials of blood pressure-lowering medications. Hypertension 2010, 56, 1060-1068. [CrossRef]

57. SHEP Cooperative Research Group. Prevention of stroke by antihypertensive drug treatment in older persons with isolated systolic hypertension. Final results of the Systolic Hypertension in the Elderly Program (SHEP). JAMA 1991, 265, 3255-3264. [CrossRef]

58. Kostis, J.B.; Cabrera, J.; Cheng, J.Q.; Cosgrove, N.M.; Deng, Y.; Pressel, S.L.; Davis, B.R. Association between chlorthalidone treatment of systolic hypertension and long-term survival. JAMA 2011, 306, 2588-2593. [CrossRef]

59. Haller, H.; Ito, S.; Izzo, J.L., Jr.; Januszewicz, A.; Katayama, S.; Menne, J.; Mimran, A.; Rabelink, T.J.; Ritz, E.; Ruilope, L.M.; et al. Olmesartan for the delay or prevention of microalbuminuria in type 2 diabetes. N. Engl. J. Med. 2011, 364, 907-917. [CrossRef]

60. Menne, J.; Ritz, E.; Ruilope, L.M.; Chatzikyrkou, C.; Viberti, G.; Haller, H. The Randomized Olmesartan and Diabetes Microalbuminuria Prevention (ROADMAP) observational follow-up study: Benefits of RAS blockade with olmesartan treatment are sustained after study discontinuation. J. Am. Heart Assoc. 2014, 3, e000810. [CrossRef]

61. Dahlof, B.; Sever, P.S.; Poulter, N.R.; Wedel, H.; Beevers, D.G.; Caulfield, M.; Collins, R.; Kjeldsen, S.E.; Kristinsson, A.; McInnes, G.T.; et al. Prevention of cardiovascular events with an antihypertensive regimen of amlodipine adding perindopril as required versus atenolol adding bendroflumethiazide as required, in the Anglo-Scandinavian Cardiac Outcomes Trial-Blood Pressure Lowering Arm (ASCOT-BPLA): A multicentre randomised controlled trial. Lancet 2005, 366, 895-906. [CrossRef]

62. Gupta, A.; Mackay, J.; Whitehouse, A.; Godec, T.; Collier, T.; Pocock, S.; Poulter, N.; Sever, P. Long-term mortality after blood pressure-lowering and lipid-lowering treatment in patients with hypertension in the Anglo-Scandinavian Cardiac Outcomes Trial (ASCOT) Legacy study: 16-year follow-up results of a randomised factorial trial. Lancet 2018, 392, 1127-1137. [CrossRef]

63. UK Prospective Diabetes Study Group. Tight blood pressure control and risk of macrovascular and microvascular complications in type 2 diabetes: UKPDS 38. BMJ 1998, 317, 703-713. [CrossRef]

64. Holman, R.R.; Paul, S.K.; Bethel, M.A.; Neil, H.A.; Matthews, D.R. Long-term follow-up after tight control of blood pressure in type 2 diabetes. N. Engl. J. Med. 2008, 359, 1565-1576. [CrossRef] [PubMed]

65. Lonn, E.M.; Bosch, J.; Lopez-Jaramillo, P.; Zhu, J.; Liu, L.; Pais, P.; Diaz, R.; Xavier, D.; Sliwa, K.; Dans, A.; et al. Blood-Pressure Lowering in Intermediate-Risk Persons without Cardiovascular Disease. N. Engl. J. Med. 2016, 374, 2009-2020. [CrossRef] [PubMed]

66. Cushman, W.C.; Davis, B.R.; Pressel, S.L.; Cutler, J.A.; Einhorn, P.T.; Ford, C.E.; Oparil, S.; Probstfield, J.L.; Whelton, P.K.; Wright, J.T., Jr.; et al. Mortality and morbidity during and after the Antihypertensive and Lipid-Lowering Treatment to Prevent Heart Attack Trial. J. Clin. Hypertens. 2012, 14, 20-31. [CrossRef] [PubMed]

67. Wing, L.M.; Reid, C.M.; Ryan, P.; Beilin, L.J.; Brown, M.A.; Jennings, G.L.; Johnston, C.I.; McNeil, J.J.; Macdonald, G.J.; Marley, J.E.; et al. A comparison of outcomes with angiotensin-converting-enzyme inhibitors and diuretics for hypertension in the elderly. N. Engl. J. Med. 2003, 348, 583-592. [CrossRef]

68. Nelson, M.R.; Chowdhury, E.K.; Doust, J.; Reid, C.M.; Wing, L.M. Ten-year legacy effects of baseline blood pressure 'treatment naivety' in the Second Australian National Blood Pressure study. J. Hypertens. 2015, 33, 2331-2337. [CrossRef]

69. Ho, C.L.B.; Sanders, S.; Breslin, M.; Doust, J.; Reid, C.M.; Davis, B.R.; Simpson, L.M.; Brouwers, F.P.; Nelson, M.R. Legacy effect of delayed blood pressure lowering drug treatment in middle-aged adults with mildly elevated blood pressure: Systematic review and meta-analysis. J. Hum. Hypertens. 2020, 34, 261-270. [CrossRef]

70. Dusing, R. Pharmacological interventions into the renin-angiotensin system with ACE inhibitors and angiotensin II receptor antagonists: Effects beyond blood pressure lowering. Ther. Adv. Cardiovasc. Dis. 2016, 10, 151-161. [CrossRef]

71. Dahlof, B.; Devereux, R.B.; Kjeldsen, S.E.; Julius, S.; Beevers, G.; de Faire, U.; Fyhrquist, F.; Ibsen, H.; Kristiansson, K.; LederballePedersen, O.; et al. Cardiovascular morbidity and mortality in the Losartan Intervention For Endpoint reduction in hypertension study (LIFE): A randomised trial against atenolol. Lancet 2002, 359, 995-1003. [CrossRef]

72. Forrester, S.J.; Booz, G.W.; Sigmund, C.D.; Coffman, T.M.; Kawai, T.; Rizzo, V.; Scalia, R.; Eguchi, S. Angiotensin II Signal Transduction: An Update on Mechanisms of Physiology and Pathophysiology. Physiol. Rev. 2018, 98, 1627-1738. [CrossRef] [PubMed]

73. Karnik, S.S.; Unal, H.; Kemp, J.R.; Tirupula, K.C.; Eguchi, S.; Vanderheyden, P.M.; Thomas, W.G. International Union of Basic and Clinical Pharmacology. XCIX. Angiotensin Receptors: Interpreters of Pathophysiological Angiotensinergic Stimuli [corrected]. Pharmacol. Rev. 2015, 67, 754-819. [CrossRef] [PubMed]

74. Gomolak, J.R.; Didion, S.P. Angiotensin II-induced endothelial dysfunction is temporally linked with increases in interleukin-6 and vascular macrophage accumulation. Front. Physiol. 2014, 5, 396. [CrossRef] [PubMed]

75. Harrison, C.B.; Trevelin, S.C.; Richards, D.A.; Santos, C.X.C.; Sawyer, G.; Markovinovic, A.; Zhang, X.; Zhang, M.; Brewer, A.C.; Yin, X.; et al. Fibroblast Nox2 (NADPH Oxidase-2) Regulates ANG II (Angiotensin II)-Induced Vascular Remodeling and Hypertension via Paracrine Signaling to Vascular Smooth Muscle Cells. Arterioscler. Thromb. Vasc. Biol. 2021, 41, 698-710. [CrossRef]

76. Togashi, N.; Maeda, T.; Yoshida, H.; Koyama, M.; Tanaka, M.; Furuhashi, M.; Shimamoto, K.; Miura, T. Angiotensin II receptor activation in youth triggers persistent insulin resistance and hypertension-a legacy effect? Hypertens. Res. 2012, 35, 334-340. [CrossRef] [PubMed]

77. Wang, H.X.; Yang, H.; Han, Q.Y.; Li, N.; Jiang, X.; Tian, C.; Du, J.; Li, H.H. NADPH oxidases mediate a cellular "memory" of angiotensin II stress in hypertensive cardiac hypertrophy. Free Radic. Biol. Med. 2013, 65, 897-907. [CrossRef] [PubMed] 
78. Li, W.J.; Liu, Y.; Wang, J.J.; Zhang, Y.L.; Lai, S.; Xia, Y.L.; Wang, H.X.; Li, H.H. "Angiotensin II memory" contributes to the development of hypertension and vascular injury via activation of NADPH oxidase. Life Sci. 2016, 149, 18-24. [CrossRef]

79. Prasher, D.; Greenway, S.C.; Singh, R.B. The impact of epigenetics on cardiovascular disease. Biochem. Cell Biol. 2020, 98, 12-22. [CrossRef]

80. Masi, S.; Ambrosini, S.; Mohammed, S.A.; Sciarretta, S.; Luscher, T.F.; Paneni, F.; Costantino, S. Epigenetic Remodeling in Obesity-Related Vascular Disease. Antioxid. Redox Signal. 2021, 34, 1165-1199. [CrossRef]

81. Ramzan, F.; Vickers, M.H.; Mithen, R.F. Epigenetics, microRNA and Metabolic Syndrome: A Comprehensive Review. Int. J. Mol. Sci. 2021, 22, 5047. [CrossRef]

82. Advani, A.; Huang, Q.; Thai, K.; Advani, S.L.; White, K.E.; Kelly, D.J.; Yuen, D.A.; Connelly, K.A.; Marsden, P.A.; Gilbert, R.E. Long-term administration of the histone deacetylase inhibitor vorinostat attenuates renal injury in experimental diabetes through an endothelial nitric oxide synthase-dependent mechanism. Am. J. Pathol. 2011, 178, 2205-2214. [CrossRef] [PubMed]

83. Hong, Q.; Zhang, L.; Das, B.; Li, Z.; Liu, B.; Cai, G.; Chen, X.; Chuang, P.Y.; He, J.C.; Lee, K. Increased podocyte Sirtuin-1 function attenuates diabetic kidney injury. Kidney Int. 2018, 93, 1330-1343. [CrossRef] [PubMed]

84. Zhou, X.; Zang, X.; Ponnusamy, M.; Masucci, M.V.; Tolbert, E.; Gong, R.; Zhao, T.C.; Liu, N.; Bayliss, G.; Dworkin, L.D.; et al. Enhancer of Zeste Homolog 2 Inhibition Attenuates Renal Fibrosis by Maintaining Smad7 and Phosphatase and Tensin Homolog Expression. J. Am. Soc. Nephrol. 2016, 27, 2092-2108. [CrossRef]

85. Kato, M.; Natarajan, R. Epigenetics and epigenomics in diabetic kidney disease and metabolic memory. Nat. Rev. Nephrol. 2019, 15, 327-345. [CrossRef] [PubMed] 